\title{
Program SGK sebagai upaya pembentukan karakter yang kreatif dan berbudaya berbudi luhur di Kadipiro Surakarta
}

\author{
${ }^{1}$ Krisdayanti*; ${ }^{1}$ Anita Trisiana \\ ${ }^{1}$ Prodi PPKn, Universitas Slamet Riyadi, Surakarta, Indonesia \\ *Corresponding Author: \\ krisda20dayanti@gmail.com
}

$\begin{array}{llll}\text { Received: } & \text { Revised: } & \text { Accepted: } & \text { Published: } \\ \text { 25 August 2019 } & \text { 20 November 2019 } & \text { 28 November 2019 } & \text { 30 November 2019 }\end{array}$

\begin{abstract}
Abstrak
Tujuan kegiatan yang dilakukan ini adalah untuk menumbuhkan karakter anak yang kreatif dan berbudi luhur melalui kegiatan "SGK (Sekolah Gencar Karakter)" serta memberikan wadah kepada anak-anak Kelurahan Kadipiro untuk bermain, berkarya dan belajar bersama para pendidik dan Karang Taruna setempat dalam kehidupan masyarakat sehari-hari di Desa Kadipiro, Kecamatan Banjarsari, Kabupaten Surakarta Solo, Provinsi Jawa Tengah. Metode yang sudah dilaksanakan dalam kegiatan ini adalah melalui beberapa tahap, yaitu: 1) Persiapan dan sosialisasi, 2) Realisasi program, dan 3) Evaluasi dan tindak lanjut. Hasil dari penelitian ini ialah terbentuknya anak-anak yang memiliki kreativitas, berbudi luhur serta karakter yang baik. Dengan terbentuknya anak-anak yang berkualitas di Kelurahan Kadipiro akan dapat memberikan pengaruh positif serta perubahan stigma negatif dalam pendidikan anak bagi kaum marginal di seluruh Indonesia, dan di Surakarta pada khususnya. Maka dari itu, dapat disimpulkan bahwa SGK (Sekolah Gencar Karakter) Upaya Pembentukan Karakter yang Kreatif dan Berbudaya Berbudi Luhur di Kadipiro dapat terwujud nyata di lingkup masyarakat.
\end{abstract}

Kata Kunci: karakter; kreatif; budaya; Sekolah Gencar Karakter

\begin{abstract}
The purpose of this activity is to grow the character of children who are creative and virtuous through the activities of "SGK (character Gencar school)" and give the children a container Kadipiro village to play, work and learn together Teachers and the local coral Taruna in the life of daily society in Kadipiro Village, Banjarsari District, Surakarta Solo Regency, Central Java province. The method that will be done in this activity is through several stages, namely: 1) Preparation and socialization, 2) Program realization, and 3) evaluation and follow-up. The result of this study was the formation of children with creativity, nobility and good character. With the formation of quality children in Kelurahan Kadipiro will be able to give positive influence as well as changes in the negative stigma in children's education for the marginal people throughout Indonesia, and in Surakarta in particular. Therefore, it can be concluded that SGK (the school of character Gencar) efforts to build to build creative and culturally-virtuous character in Kadipiro can be realized in real society.
\end{abstract}

Keywords: Character; Creative; Culture; Sekolah Gencar Karakter 


\section{PENDAHULUAN}

Sekolah Gencar Karakter (SGK) adalah suatu progam kegiatan yang dilakukan bertujuan untuk memperbaiki karakter anak pada khususnya tingkat TK sampai dengan SD, kegiatan ini dilakukan berkelompok dengan mengajak anak bermain, belajar bersama, menyanyi dan menari hingga menonton film edukasi sampai olahraga dan banyak lagi kegiatan lainya.

Menurut Trisiana (2013), SGK sesuai dengan kebijakan pemerintah yang secara serentak dan bersinergi untuk memperkuat karakter bangsa, maka dalam pendidikan kewarganegaraan pembelajaran dapat mengintegrasikan nilai-nilai karakter juga sehingga muncul pengetahuan dan perilaku warga negara yang mampu mencerminkan nilai moral.

Karakter sendiri adalah suatu cara pola berpikir dan berperilaku yang dijadikan sebagai sesuatu ciri yang khas setiap masing masing pribadi seseorang untuk hidup dan saling bekerjasama, baik dalam kawasan keluarga, masyarakat, hingga bangsa dan negara. Dengan tinjauan psikologis dan socio-cultural, membetuk karakter dari dalam diri seseorang merupakan kegunaan dari segala kemampuan seseorang manusia (kognitif, afektif, konatif, dan psikomotorik) dalam kondisi hubungan sosial budaya (dalam lingkungan keluarga, satuan pendidikan, dan masyarakat sekitar) dan berlangsung sepanjang zaman kehidupan. (Kementerian Pendidikan Nasional, 2010).

Menurut Hidayatullah (2010), Pendidikan karakter "perlu diterapkan ke seluruh bagian kehidupan, termasuk lingkungan sekolah. Lembaga kependidikan, khususnya sekolah dijadikan sebagai tempat yang terpenting untuk pembentukan karakter". Hal ini ditujukan agar peserta didik mencakup seluruh ucapan, tindakan, dan tingkah laku untuk mewujudkan karakter yang baik dan kuat. Pemahaman serta penanaman pendidikan karakter secara mendalam bisa dilakukan untuk memfilter kebudayaan asing yang bisa merusak moral pemuda pemudi penerus bangsa. Oleh sebab itu lembaga pendidikan harus bisa menjadi jembatan penghubung guna memberi yang mendalam terhadap pendidikan karakter.

Pendidikan karakter pada zaman sekarang merupakan pokok masalah yang seringkali diperdebatkan dalam lingkungan pendidikan. Pendidikan ialah salah satu cara yang di dalamnya adapun suatu ketentuan dan langkah-langkah yang mesti dimiliki oleh setiap siswa. Setiap siswa mempunyai tanggung jawab yang sama dalam rangkaian pembelajaran. Pendidikan dijadikan tiang utama untuk memajukan pemuda pemudi penerus bangsa demi perkembangan pengetahuan anak. Perkembangan pengetahuan tersebut nantinya akan membentuk kepribadian atau karakter anak.

Meluasnya perilaku hidup yang tidak baik dan budaya kekerasan, atau mendomisili bahasa ekonomi dan politik, memahami atau tidak, telah mempengaruhi perubahan karakter anak-anak bangsa, sehingga mengakibatkan nilai-nilai luhur dan kearifan sikap hidup tidak mengalami perubahan. Anak-anak sekarang mudah sekali melontarkan bahasa oral dan bahasa tubuh yang cenderung terpengaruhi oleh gaya bicara yang kasar dan tidak sopan. Nilai-nilai akhlak dan keindahan telah terkucilkan dan tidak berkembang oleh gaya hidup instan dan tidak berubah (Purwanto, 2011).

Pendidikan berbasis karakter di zaman sekarang ini memang telah lama tenggelam. Pembelajaran di sekolah yang seperti pendidikan kewarganegaraan dan pendidikan agama, yang harusnya dapat dijadikan filter guna menghalangi perkembangan meluasnya budaya kekerasan, dinilai telah berganti menjadi mata pelajaran berbasis memberi doktrin mendalam yang sematamata memberi pengajaran dan memberi ajaran terus-menerus dengan nilai baik dan buruk saja, dengan tidak diimbangkan dengan sistem pembiasaan dengan cara mendalam yang dapat membangkitkan peserta didik untuk bertingkahlaku dan bertindak sesuai dengan nilai budaya luhur. Akibat model indoktrinasi yang sekian lama dalam lingkungan pendidikan, tanpa disadari atau tidak, turut merubah perilaku anak-anak condong menjadi pribadi egois, baik terhadap pribadi sendiri ataupun sesama. Mereka tidak lagi mempunyai kesadaran d e ngan sesama, lunturnya nilai kasih sayang, dan sibuk dengan kehidupannya sendiri yang condong bergairah 
dengan tingkat kemerosotan moral yang sudah berada pada titik prihatin yang tidak bisa di wajarkan (Purwanto, 2011).

Pendidikan di sekolah tidak lagi memadai hanya dengan memberi pengajaran anak didik membaca, menulis, dan berhitung, kemudian lulus ujian dan kemudian dapat pekerjaan yang baik. Sekolah harus dapat mengajarkan anak didik untuk dapat mengambil keputusan apa yang baik dan buruk. Sekolah juga harus menolong orang tua dengan maksud menemukan tujuan hidup setiap anak didik (Hidayatullah, 2010). Sesuai dengan anggapan di atas, dapat kita simpulkan bahwa pendidikan yang dilakukan disekolah dimaksudkan bisa memajukan kecakapan pikiran sekalian membentuk karakter anak didik yang baik untuk mencapai tujuan hidup dalam kehidupan.

Karakter yang terdapat pada anak di akibatkan oleh faktor internal dan faktor eksternal. Faktor internal dipengaruhi oleh keadaan psikologis anak dan lingkungan keluarga, sedangkan faktor eksternal dipengaruhi oleh lingkungan bermain anak. Kedua faktor tersebut sangat mengakibatkan memajukan proses membentuk karakter pada anak. Karakter yang ada pada anak dapat mempengaruhi kemampuan berpikir anak dalam melakukan suatu sikap dalam kehidupan sehari-hari.

Lembaga pendidikan, terkhusus sekolah dilihat sebagai tempat yang terpenting guna membentuk karakter anak didik. Hal ini ditujukan supaya anak didik dalam seluruh ucapan, tindakan, dan tingkah laku menggambarkan karakter yang bermanfaat dan kokoh (Hidayatullah, 2010).

Berdasarkan penjelasan di atas dapat tarik kesimpulan bahwa membentuk karakter anak didik yang bermanfaat bisa dikerjakan di tempat ia menjalani pendidikan mulai dini dari pendidikan anaak usia dini taman kanak-kanak, sekolah dasar, sekolah menengah, sampai dengan perguruan tinggi.

Memperhatikan pentingnya karakter dalam membangkitkan sumber daya manusia (SDM) yang kokoh, perlu adanya pendidikan karakter yang di kerjakan dengan tepat. Dapat di jelaskan bahwa membentuk karakter merupakan suatu kesatuan yang utuh yang bisa untuk di pisahkan mengenai kehidupan. Oleh sebab itu diperhatikann kepedulian oleh semua pihak, baik di pemerintah, masyarakat, keluarga maupun sekolah. Kondisi seperti ini akan membantu membangun jika seluruh bagian yan mempunyai kesadaran bersama dalam membangun pendidikan karakter. Dengan hal tersebut, pendidikan karakter harus memuat seluruh sudut pandang kehidupan termasuk dalam lembaga pendidikan. Idealnya membentuk atau mendidik karakter menggabungkan ke semua sudut pandang kehidupan, termasuk kehidupan sekolah (Hidayatullah, 2010)

Perkembangan IPTEK yang sangat cepat dalam era globalisasi sekarang ini mengakibatkan perubahan perilaku yang berbeda pada pribadi individu. Menurut Dahliani, dkk. (2015) bahwa globalisasi dapat mengakibatkan kearifan lokal melalui pola pemikiran manusia. Dahulu semua hal dikerjakan dengan cara manual, tetapi sekarang seluruh sesuatu serba canggih memasuki dunia digital. Jika dulu untuk memperoleh sesuatu seorang mesti pergi ke suatu tempat sampai sekarang guna memperoleh sesuatu yang kita inginkan cukup dengan online saja. Bermacam-macam kemudahan telah diberikan oleh dunia digital. Hal ini jauh berbanding terbalik dengan zaman dulu yang segala sesuatu membutuhkan suatu usaha dan upaya keras guna memperoleh sesuatu hal yang kita inginkan.

Tidak saja pada orang tua, kehidupan anak-anak juga dapat terkena pengaruh dan mengalami peralihan bersama kemajuan teknologi sekarang ini. Anak-anak era sekarang, terkhusus anak-anak sekolah dasar sudah tidak mau bermain permainan trasisional sebagaimana dahulu kala. Terlebih lagi anak-anak zaman sekarang sudah tidak mengenal permainan kuno yang dilakukan oleh orangtuanya dulu. Permainan digital semacam: playstation dan game online merupakan permainan yang banyak disukai dan sering dillakukan oleh anak-anak. Seringnya, permainan-permainan digital tersebut menjadikan mereka gemar untuk selalu memainkan dan 
melalaikan kehidupan nyata, karena dengan gadget yang mereka punya, mereka bebas menentukan dan bertukar-tukar permainan sesuai dengan kegemaran mereka. Jadi kalau bosan mereka mencari lagi dengan yang lain lebih asyik.

Kelurahan Kadipiro adalah sebuah Sekolah Dasar yang terletak Kelurahan Kadipiro di kota Surakarta atau Solo. Kelurahan Kadipiro terletak di kota Surakarta Solo yang berprovinsi di Jawa Tengah. Kota Surakarta Solo sering disebut juga sebagai kota budaya dan pelajar. Kota ini dikatakan sebagai kota pelajar karena di wilayah Surakarta Solo itu sendiri didapati sarana dan prasarana sekolah dan universitas yang mewah, bermutu, serba cukup kualitasnya dan sudah terakreditasi secara baik di dunia pendidikan Indonesia Surakarta Solo memiliki banyak kecamatan yang di dalamnya terdiri dari sekolah-sekolah. Salah satunya adalah Kelurahan Kadipiro. Kelurahan Kadipiro berada di wilayah Joglo dan sekitarnya yang cukup luas. Ironinya, sebagai bagian dari kota pelajar tersebut lingkungan ini tergolong ke dalam lingkungan tidak sehat karena kurang terjaga kebersihannya. Banyak faktor yang mempengaruhi lingkungan tersebut, baik dari segi pendidikan, kesehatan serta keamanan.

Rendahnya pendidikan dari warga kelurahan Kadipiro merupakan masalah yang sangat krusial karena kita tau fasilitas sekolah di Surakarta Solo sangat terjamin, tetapi kenyataannya semakin meluasnya warga Surakarta sendiri yang rendahnya kepedulian terhadap pendidikan. Bermula dari pendidikan yang masih rendah, masyarakat kelurahan belum cukup memahami dengan jalan apa untuk memelihara lingkungan, hasilnya lingkungan menjadi tercemar kotor dan kualitas kesehatan memburuk karena lingkungan yang kurang sehat awal dari datangnya penyakit.

Merosotnya kualitas kesehatan masyarakat sendiri dialami pengaruhnya oleh seorang pribadi anggota keluarga, termasuk anak-anak. Anak-anak yang hidup di lingkungan tercemar dan kotor juga akan menjadi kedala dalam proses menuntut ilmu dan perasaan lalai belajar bertambah tinggi. Persoalan ini akan berkesinambungan berputar menggambarkan peredaran peningkatan kemiskinan jika di abaikan saja. Pendidikan yang wajar dan baik bbegitu penting diperlukan guna meningkatkan tingkat kehidupan suatu pribadi individu, terpenting anak-anak. Anak -anak merupakan tiang terpenting yang melanjutkan perjuangan bangsa yang akan mengangkat bangsa kita dalam kemerosotan atau kemajuan. Hal itu bersangkutan dengan merendahnya masyarakat berpendidikan di wilayah Kelurahan Kadipiro harus kita tingkatkan kualitasnya berawal dari anak-anak di daerah tersebut. Pengembangan pendidikan dalam masalah ini tidak semata-mata pendidikan resmi (SD, SMP,SMA), namun juga pendidikan tidak resmi (kursus).

Dengan mengikuti pendidikan resmi (SD, SMP,SMA) dan tidak resmi (kursus) ini diharapkan anak-anak tidak semata-mata pandai dari segi akademis, namun mereka juga harus mampu memajukan kecekatan untuk memperbaiki daerahnya. Dengan pendidikan yang teratur, maka pengetahuan yang bertambah luas akan membawa anak pada keinginan dan kecakapannya untuk memelihara lingkungannya. Memandang target sasaran kepada anak-anak diharapkan mampu merantas rantai kemalasan dan kesusahan supaya mereka tidak makin bertambah masuk ke zona lingkaran tempat tinggalnya tersebut. Dengan membagikan pendidikan terhadap anakanak di daerah Kelurahan Kadipiro, mereka hendak merealisasikan dan memicu orang tuanya mengerti betapa pentingnya pendidikan dan kesehatan lingkungan.

\section{METODE}

Metode yang sudah dilaksanakan dalam kegiatan ini adalah melalui beberapa tahap, yaitu:

1. Persiapan dan sosialisasi, menurut Kamus Besar Bahasa Indonesia berarti usaha menyampaikan kepada masyarakat mengakibatkan sesuatu menjadi diketahui, dimengerti, dirasakan oleh masyarakat atau pemasyarakatan. Tahap awal melaksanakan kegiatan ini adalah melaksanakan persiapan tempat pelaksanaan, baik berupa penataan ruang maupun kelengkapan peralatan. Selanjutnya mengadakan pemasyarakatan terhadap warga sekitar, 


\section{Indonesian Journal of Community Services \\ Volume 1, No. 2, November 2019 \\ http://jurnal.unissula.ac.id/index.php/ijocs \\ DOI: http://dx.doi.org/10.30659/ijocs.1.2.152-164}

terutama para ibu dan pemuda Karang Taruna di lingkungan kawasan Kelurahan Kadipiro, Kecamatan Banjarsari, Kota Surakarta bersangkut paut dengan adanya penyuluhan "SGK (Sekolah Gencar Karakter) seperti usaha yang berguna membangun karakter anak yang kreatif, berbudi pekerti, dan sadar akan pentingnya kesehatan lingkungan. Selain itu, target dari permasyarakatan ini juga berguna mengumpulkan peran serta masyarakat dalam melaksanakan kegiatan yang telah terprogram ini. Oleh sebab itu, program dapat dijalankan dengan baik karena terkait kerjasama sosial dengan wilayah setempat.

2. Realisasi program, Menurut Dedi Nordiawan (2010:115) Realisasi adalah: "Proses yang harus diwujdkan untuk menjadi kenyataan dan pelaksanaan yang nyata agar realisasi dapat sesuai dengan harapan diinginkan". Kegiatan yang dilaksanakan dalam program ini adalah berbentuk pendidikan formal dan non-formal sebagai wadah anak-anak di Kawasan Kelurahan Kadipiro, Kecamatan Banjarsari, Kota Surakarta untuk mengembangkan karakter, daya cipta, kepribadian untuk hidup kondusif serta internalisasi nilai-nilai kehidupan. Pendidikan non-formal (kursus) ini mendatangkan para pendidik dari mahasiswa mahasiswi UNISRI yang berpengalaman dalam bagian keahlian yang berkepentingan. Dengan adanya tenaga pengajar tersebut dimaksudkan mampu untuk menyampaikan pengetahuan dan pemahaman berkaitan dengan pola sistem pendidikan non-formal yang selaras diterapkan terhadap anak.

Penjadwalan kegiatan pendidikan non-formal ini diadakan dua minggu sekali lebih tepatnya pada hari minggu. Kerja sama dengan perkumpulan pemuda-pemudi Karang Taruna di Kawasan Kelurahan Kadipiro, Kecamatan Banjarsari, Kota Surakarta, juga menjadi salah satu pilihan cara yang tepat untuk berdaya guna dalam program kegiatan ini. Selain aktivitas menyelesaikan tugas sekolah atau PR (Pekerjaan Rumah) dari sekolah dengan bersama dan pendidikan ketrampilan guna memajukan kreativitas anak seperti: menari, bernyanyi, hasta karya (prakarya membuat gelang dengan tali kur), berdiskusi atau belajar kelompok, menonton film edukasi yang akan ditonton secara bersama-sama oleh anak-anak. Hendak pula diadakan modifikasi kegiatan, seperti mengadakan kegiatan olah raga atau latihan jasmani sesuai dengan apa yang di inginkan anak dan wisata edukasi guna menambah wawasan pengetahuan mereka akan adanya sesuatu hal yang baru Mengadakan kegiatan dan program kreatif ini hendaklah mampu menambah minat dan keinginan anak-anak untuk aktif berpartisipasi dalam program kegiatan ini, sehingga program kegiatan ini dapat berlangsung dengan lancar.

3. Evaluasi dan tindak Lanjut, Menurut Wirawan (2012:7) evaluasi adalah: "Riset untuk menghimpun, mengkaji, dan mengemukakan informasi yang berguna mengenai sasaran evaluasi, selanjutnya memperhitungkan dan membandingkan dengan parameter evaluasi dan hasilnya digunakan untuk mengambil pertimbangan mengenai sasaran evaluasi tersebut". Evaluasi ini kami laksanakan pada tiap selesai pertemuan setelah melaksanakan pendidikan non-formal tersebut dilaksanakan bersama-sama sejalan dengan mengadakan rapat evaluasi dengan berdiskusi permasalahan dan menggali jalan keluar untuk kegiatan selanjutnya.

\section{HASIL DAN PEMBAHASAN}

Sekolah Gencar Karakter (SGK) yaitu suatu progam kegiatan yang dilakukan bertujuan untuk memperbaiki atau membentuk karakter anak pada khususnya tingkat TK sampai dengan SD, Pembahasan dibawah ini menjelaskan tentang kegiatan yang di lakukan mulai dari mengajak anak belajar bersama hingga bermain menggunakan alat tradisional sehingga dapat menambah wawasan sampai mengenal budaya tradisional. 
Tabel 1. Jadwal Program Kegiatan (SGK)

\begin{tabular}{|c|c|c|c|c|c|c|c|c|c|c|c|c|c|c|c|c|}
\hline \multirow{2}{*}{ No } & \multirow{2}{*}{ Kegiatan } & \multicolumn{3}{|c|}{ Bulan I } & \multicolumn{3}{|c|}{ Bulan II } & \multicolumn{3}{|c|}{ Bulan III } & \multicolumn{3}{|c|}{ Bulan IV } & \multicolumn{3}{|c|}{ Bulan V } \\
\hline & & $\mathrm{I}$ & II & III & $\mathrm{I}$ & II & III & $\mathrm{I}$ & II & III & $\mathrm{I}$ & II & III & I & II & III \\
\hline \multirow[t]{4}{*}{1} & Intensitas 1 & & & & & & & & & & & & & & & \\
\hline & Persiapan awal dan perizinan & V & V & V & V & V & V & $\mathrm{V}$ & $\mathrm{V}$ & $\mathrm{V}$ & V & V & V & $\mathrm{V}$ & $\mathrm{V}$ & V \\
\hline & $\begin{array}{l}\text { Publikasi dan Sosialisasi } \\
\text { Warga }\end{array}$ & V & $\mathrm{V}$ & V & V & $\mathrm{V}$ & V & V & $\mathrm{v}$ & V & V & V & V & $\mathrm{V}$ & $\mathrm{V}$ & v \\
\hline & $\begin{array}{l}\text { Pengadaan Taman baca atau } \\
\text { perpustakaan }\end{array}$ & $\mathrm{V}$ & $\mathrm{V}$ & $\mathrm{V}$ & $\mathrm{V}$ & $\mathrm{V}$ & $\mathrm{V}$ & $\mathrm{V}$ & $\mathrm{V}$ & $\mathrm{V}$ & $\mathrm{V}$ & $\mathrm{V}$ & $\mathrm{V}$ & $\mathrm{V}$ & $\mathrm{V}$ & V \\
\hline \multirow[t]{4}{*}{2} & Intensitas 2 & & & & & & & & & & & & & & & \\
\hline & $\begin{array}{l}\text { Mengerjakan PR sekolah dan } \\
\text { belajar bersama }\end{array}$ & V & V & $\mathrm{V}$ & V & $\mathrm{V}$ & V & $\mathrm{V}$ & $\mathrm{V}$ & V & $\mathrm{V}$ & V & V & $\mathrm{V}$ & $\mathrm{V}$ & V \\
\hline & Menari dan Menyayi & $\mathrm{V}$ & $\mathrm{V}$ & $\mathrm{V}$ & $\mathrm{V}$ & $\mathrm{V}$ & $\mathrm{V}$ & $\mathrm{V}$ & $\mathrm{V}$ & $\mathrm{V}$ & $\mathrm{V}$ & $\mathrm{V}$ & $\mathrm{V}$ & $\mathrm{V}$ & $\mathrm{V}$ & $\mathrm{V}$ \\
\hline & Outbond & $\mathrm{V}$ & $\mathrm{V}$ & $\mathrm{V}$ & $\mathrm{V}$ & $\mathrm{V}$ & $\mathrm{V}$ & $\mathrm{V}$ & $\mathrm{V}$ & $\mathrm{V}$ & $\mathrm{V}$ & $\mathrm{V}$ & $\mathrm{V}$ & $\mathrm{V}$ & $\mathrm{V}$ & $\mathrm{V}$ \\
\hline \multirow[t]{4}{*}{3} & Intensitas 3 & & & & & & & & & & & & & & & \\
\hline & Melukis & V & V & V & V & $\mathrm{V}$ & $\mathrm{V}$ & $\mathrm{V}$ & $\mathrm{V}$ & $\mathrm{V}$ & $\mathrm{V}$ & V & V & V & $\mathrm{V}$ & $\mathrm{V}$ \\
\hline & $\begin{array}{l}\text { Menonton Film dan } \\
\text { berdiskusi }\end{array}$ & $\mathrm{V}$ & $\mathrm{V}$ & $\mathrm{V}$ & $\mathrm{V}$ & $\mathrm{V}$ & $\mathrm{V}$ & $\mathrm{V}$ & $\mathrm{V}$ & $\mathrm{V}$ & $\mathrm{V}$ & $\mathrm{V}$ & V & $\mathrm{V}$ & V & V \\
\hline & Sepak Bola & $\mathrm{V}$ & $\mathrm{V}$ & $\mathrm{V}$ & $\mathrm{V}$ & $\mathrm{V}$ & $\mathrm{V}$ & $\mathrm{V}$ & $\mathrm{V}$ & $\mathrm{V}$ & $\mathrm{V}$ & $\mathrm{V}$ & $\mathrm{V}$ & $\mathrm{V}$ & $\mathrm{V}$ & $\mathrm{V}$ \\
\hline \multirow[t]{4}{*}{4} & Intensitas 4 & & & & & & & & & & & & & & & \\
\hline & Membuat hasta karya & $\mathrm{V}$ & $\mathrm{V}$ & $\mathrm{V}$ & $\mathrm{V}$ & $\mathrm{V}$ & $\mathrm{V}$ & $\mathrm{V}$ & $\mathrm{V}$ & $\mathrm{V}$ & $\mathrm{V}$ & $\mathrm{V}$ & $\mathrm{V}$ & $\mathrm{V}$ & $\mathrm{V}$ & $\mathrm{V}$ \\
\hline & Permainan Tradisional & $\mathrm{V}$ & $\mathrm{V}$ & $\mathrm{V}$ & $\mathrm{V}$ & $\mathrm{V}$ & $\mathrm{V}$ & $\mathrm{V}$ & $\mathrm{V}$ & $\mathrm{V}$ & $\mathrm{V}$ & $\mathrm{V}$ & $\mathrm{V}$ & $\mathrm{V}$ & $\mathrm{V}$ & $\mathrm{V}$ \\
\hline & Wisata Edukasi & $\mathrm{V}$ & $\mathrm{V}$ & $\mathrm{V}$ & $\mathrm{V}$ & $\mathrm{V}$ & $\mathrm{V}$ & $\mathrm{V}$ & $\mathrm{V}$ & $\mathrm{V}$ & $\mathrm{V}$ & $\mathrm{V}$ & $\mathrm{V}$ & $\mathrm{V}$ & $\mathrm{V}$ & $\mathrm{V}$ \\
\hline \multirow[t]{4}{*}{5} & Intensitas $\mathbf{5}$ & & & & & & & & & & & & & & & \\
\hline & Evaluasi & $\mathrm{V}$ & $\mathrm{V}$ & $\mathrm{V}$ & $\mathrm{V}$ & $\mathrm{V}$ & $\mathrm{V}$ & $\mathrm{V}$ & $\mathrm{V}$ & $\mathrm{V}$ & $\mathrm{V}$ & $\mathrm{V}$ & $\mathrm{V}$ & $\mathrm{V}$ & $\mathrm{V}$ & $\mathrm{V}$ \\
\hline & Pembuatan Laporan & $\mathrm{V}$ & $\mathrm{V}$ & $\mathrm{V}$ & $\mathrm{V}$ & $\mathrm{V}$ & $\mathrm{V}$ & $\mathrm{V}$ & $\mathrm{V}$ & $\mathrm{V}$ & $\mathrm{V}$ & $\mathrm{V}$ & $\mathrm{V}$ & $\mathrm{V}$ & $\mathrm{V}$ & $\mathrm{V}$ \\
\hline & Delannran Hocil Kocriaton & v & v & v & v & v & v & v & $\mathrm{v}$ & $v^{\prime}$ & $\mathrm{v}$ & & $v$ & $\mathrm{v}$ & $\mathrm{v} f$ & $\bar{v}$ \\
\hline
\end{tabular}

\section{Kegiatan Intensitas I}

a) Kegiatan dari mulai persiapan awal dan perizinan ini dilakukan untuk melihat kondisi lapangan yaitu kebutuhan yang diperlukan masyarakat saat itu dari beberapa faktor masalah yang memang harus ditangani, dilanjut proses perencanaan hingga masuk proses perizinan.

b) Publikasi dan Sosialisasi, melalui kegiatan ini supaya apa yang telah kami rancangkan dapat diketahui masyarakat umum bertujuan untuk mendapat dukungan dari segala pihak yang terkait dan supaya masyarakat juga mengetahui maksud dari beberapa program yang akan kami adakan dalam setiap kegiatan.

c) Pengadaan taman baca atau perpustakan, disini menghasilkan anak-anak yang suka membaca dan menciptakan budaya suka membaca untuk mengurangi tingkat rendahnya baca anak-anak pada usia dini atau usia sekolah dasar.

\section{Kegiatan Intensitas II}

a) Mengerjakan Pekerjaan Rumah dari Sekolah dan belajar bersama di sini menghasilkan anak-anak yang berkarter disiplin dan membentuk sikap sosial yang dimana didalamnya mengajarkan toleransi, saling bermusyawarah, saling mengahargai sesama dan juga kekompakan antar teman dapat terwujud dalam kegiatan ini.

b) Menari dan menyanyi, di sini menghasilkan anak-anak kreativitas anak dalam meningkatkan kearifan lokal yaitu berupa tarian dan lagu-lagu daerah. Selain itu 
juga untuk mnencari dan mengembangkan bakat dan minat (potensi) yang dimiliki anak-anak.

c) Outbond, di sini menghasilkan kegiatan yang dimana anak menjadi terbentuk jiwa sportifitas, kejujuran, saling menghargai, kompak, kerja kelompok sehingga anak menjadi berkarakter baik. Dan juga kegiatan ini menyehatkan bagi anakanak tersebut.

\section{Kegiatan Intensitas III}

a) Melukis, dalam kegiatan ini anak menghasilkan kreatifitas, dan gagasan yang baru. Sehingga anak bisa mengekpresikan hal-hal yang baru. Dan juga kegiatan ini membentuk daya imajinasi anak dalam menyimpulkan suatu objek.

b) Menonton film dan berdiskusi, dalam kegiatan ini anak bisa menyaring suatu hal dari yang anak-anak lihat, sehingga dapat memilah hal yang baik dan buruk dan bisa mendikusikan apa yang mereka alami dengan rekan sebaya.

c) Sepak bola, kegiatan ini mengajarkan nilai dalam perlombaan dan hasilnya setiap anak dapat memahami nilai-nilai yang ditanamkan dalam perlombaan seperti sportifitas, kerja tim, kejujuran, dan lain sebagainya.

\section{Kegiatan Intensitas IV}

a) Membuat hasta karya, dalam kegiatan ini anak bisa membuat suatu produk dari hasil nya sendiri. semisal membuat gelang tangan dari tali kur, nilai yang bisa kami tanamkan disini adalah anak bisa membuat karya sendiri, dan anak mampu menciptakan suatu produk. Dari kegiatan ini anak bisa menghargai suatu proses dan menghargai barang ciptaan sendiri ataupun orang lain.

b) Permainan tradisional, dalam kegiatan ini anak-anak menjadi lebih suka bermain dengan permainan yang mereka anggap dulunya kuno dan tidak mengasikan. Serta anak-anak juga bisa belajar menghargai warisan leluhur. Dalam kegiatan ini juga mengurang tingkat pemakaian atau kecanduan anak terhadap gadget serta meningkatkan interaksi sosial dengan permainan kelompok.

c) Wisata edukasi, di sini menghasilkan anak mulai mengenal kearifan lokal dan tempat wisata yang ada di wilayah Surakarta sendiri seperti taman cerdas, taman balaikambang dan taman kebun binatang jurug sehingga membuat anak wisata yang bermanfaat dan ada nilai dan ilmu yang bisa diambil dibanding dengan hanya di rumah dan ke mall dan sebagainya.

\section{Kegiatan Intensitas $\mathbf{V}$}

a) Evaluasi kegiatan, ini digunakan penelitan untuk mengevalusi kegiatan yang selama ini diselenggarakan untuk menjadi bahan perbaikan dikegiatan berikutnya.

b) Pembuatan laporan, kegiatan ini berfungsi untuk menyusun kegiatan-kegiatan yang telah diselenggarakan untuk pelaporan dalam bentuk tertulis atau dokumentasi.

c) Pelaporan hasil kegiatan, ini digunakan untuk melaporkan kegiatan dan hasilhasilnya sebagai bentuk wujud dari tanggung jawab peneliti beserta timnya.

\section{Program Pembentukan Karakter (SGK)}

Sebelum dinamakan dengan pendidikan karakter, pendidikan berusaha untuk membentuk kepribadian, sehingga membentuk ciri-ciri tertentu yang bersifat positif, termasuk usaha untuk menuntun, mengarahkan, dan menyesuaikan diri dengan lingkungan sosial-budaya sebagai tempat bersangkutan berada. Di dalamnya termasuk budi, akal, cara berfikir, cara bertingkah laku serta kepandaian yang dimiliki. 
Proses membentuk karakter dapat berawal dari keluarga, masyarakat, dan sekolah. Selanjutnya untuk membentuk karakter dipertegas dalam lingkup pendidikan moral (akhlak), sama halnya dengan Pendidikan Moral Pancasila dan keahlian poin-poin butir nilai-nilai Pancasila. Segala sesuatu tersebut dijalankan di semua jenjang pendidikan dan melalui peenyuluhan P-4, yang selesai sepaham dengan selesainya masa Orde Baru.

Sekarang kita harus merasa waswas dengan semakin banyaknya informasi di berbagai macam media massa perihal kenakalan remaja, yang bisa jadi hal tersebut juga dapat pula terjadi di lingkungan dan dialami oleh anak didik kita sendiri. Tentu saja hal ini tidak dapat begitu mudahnya seperti ini, bahkan dirasa sebagai sesuatu hal yang terampil dan normal berlangsung. Oleh sebab itu semua kenakalan yang berlangsung bukan disebabkan oleh satu aspek pemicu, melainkan banyak aspek masalah. Demikianlah keadaan kekhawatiran tersebut harus mencari langkah selanjutnya untuk memulihkan jati diri bangsa sebagai bangsa yang besar melalui pendidikan karakter.

Adakalanya penafsiran pendidikan karakter berlangsung ketidaktepatan pemahaman yang terjadi di masyarakat. Apalagi di dalam dunia pendidikan itu sendiri, sebagaimana diungkapkan Dharma Kesuma dkk. antara lain:

1. Pendidikan karakter $=$ pendidikan untuk pelajaran agama dan PKn dikarenakan suatu tanggung jawab seorang guru PPKn dan Agama.

2. Pendidikan karakter $=$ pendidikan untuk pelajaran budi pekerti untuk mendidik agar mengerti akan sopan santun dalam berbudi pekerti.

3. Pendidikan karakter $=$ pendidikan sifat karakter yang dimana-mana itu diajarkan di rumah oleh orang tua.

4. Pendidikan karakter $=$ pendidikan mata kuliah baru bisa di luar sekolah maupun di dalam sekolah.

Anggapan yang tidak tepat tersebut mungkin saja sempat beredar, sehingga perlu adanya pengembalian makna yang sebenarnya. Dalam usaha untuk menuju pengertian dan pemahaman pendidikan karakter diperlukan adanya keterlibatan berbagai pihak secara bersama-sama seperti: pendidikan dalam kehidupan keluarga, masyarakat, dan sekolah sebagai lembaga pendidikan; kurikulum pada setiap mata pelajaran; bahkan materi pelajaran yang diberikan harus mengandung makna pembentukan karakter. Dengan demikian, untuk mengetahui dan memahami pendidikan karakter perlu diketahui makna dari pengertian pendidikan karakter itu sendiri.

Pendidikan menjadi salah satu usaha yang dipergunakan untuk memajukan dalam bidang ranah kognitif, afektif, dan psikomotorik.Berakhirnya puncak dari bidang ranah kognitif adalah berkembang dan majunya kemampuan berpikir otak dan kemampuan pengetahuan yang secara akademik, dalam bidang ranah afektif berakhir pada puncak terealisasinya karakter pribadi individu peserta didik, dan ranah psikomotorik akan berakhir pada puncak kompeten dalam bidang kujuruan dan tingkah lakunya seorang pribadi peserta didik. Oleh sebab itu, yang harusnya mampu terlaksana dengan baik dari tujuan pendidikan yang tentunya dapat untuk merealisasikan pendidikan berkarakter, sehingga sangatlah jelas bahwa pendidikan memiliki tanggungjawab yang sangat penting terhadap pembentukan karakter yang bertumpu pada apa yang menjadi kebudayaan bangsa ini.

Pembentukan karakter dapat dilakukan melalui pendidikan karakter. Yang terlebih dahulu harus dipahami dan diketahui adalah nilai-nilai karakter yang terdiri dari 18 nilai versi Kemendiknas sebagaimana tertuang berikut ini:

a) Religius, yakni ketaatan dan kepatuhan dalam memahami dan melaksanakan ajaran agama (aliran kepercayaan) yang dianut, termasuk dalam hal ini adalah sikap toleran terhadap pelaksanaan ibadah agama (aliran kepercayaan) lain, serta hidup rukun dan berdampingan. 
b) Jujur, yaitu sikap dan perilaku yang mencerminkan kesatuan antara pengetahuan, perkataan, dan perbuatan (mengetahui yang benar, mengatakan yang benar, dan melakukan yang benar), sehingga menjadikan orang yang bersangkutan sebagai pribadi yang dapat dipercaya.

c) Tolersansi, Adalah sikap keterbukaan atau saling menghargai antar suku, agama dan perbedaan pendapat lainya, dan bisa hidup rukun saling berdampingan.

d) Disiplin, Adalah suatu sikap atau bentuk tindakan yang konsisten dalam bentuk menaati peraturan atau tata tertib.

e) Kerja keras, yaitu suatu tindakan pada diri seseorang yang menunjukan tindakan sungguh sungguh terhadap tujuan atau target yang sedang di di perjuangkan.

f) Kreatif, adalah suatu sikap atau prilaku pada diri sesorang yang menunjukan hal hal baru dalam memecahkan masalah dengan cara yang unik dan mendapatkan hal hal lebih baik atau hal hal baru dari sebelumnya.

g) Mandiri, Yaitu suatu sikap pada diri seseorang yang menunjukan prilaku ketidak tergantungan pada orang lain dalam menyelesaikan beberapa hal perosalan maupun tugas.

h) Demokratis, yaitu sikap pada diri seseorang yang memperlihatkan suatu cara berpikir secara merata dan adil antara orang lain dan dirinya sendiri.

i) Rasa ingin tahu, yaitu sikap atau prilaku pada diri seseorang yang menunjukan rasa ingin tau terhadap sesuatu hal yang ia lihat maupun ia dengar, dan ia pelajari lebih lanjut.

j) Semangat kebangsaan dan nasionalisme, yaitu sikap pada diri sesorang yang mencerminkan tindakan dalam kepedulian dan mementingkan urusan bangsa dan negara ketimbang urusan pribadi.

k) Cinta tanah air, yaitu suatu sikap pada diri seseorang yang mencerminkan rasa bangga dan cinta kepada tanah air.

1) Menghargai prestasi, yaitu suatu sikap pada diri sesorang yang menunjukan dan mengapresiasi suatu penghargaan.

m) Komunikatif, suatu sikap pada diri seseorang yang menunjukan keterbukkan pada orang lain dengan cara santun atau bersahabat sehingga menimbulkan keakraban pada orang lain dan tercipta kerjasama dengan baik.

n) Cinta damai, yakni sikap pada seseorang yang menunjukan sikap damai pada seseorang dan tidak suka akan keributan dalam lingkungan masyarakat atau lingkungan lainya.

o) Gemar membaca, yaitu sikap atau kebiasaan seseorang senang akan membaca baik buku, koran dal lain sebaigainya guna ingin tau atau ingin memahami isi yang dibacanya.

p) Peduli lingkungan, yaitu sikap pada diri seseorang yang menunjukan pedulinya dengan cara menjaga atau melestarikan lingkunganya.

q) Peduli sosial, yaitu sikap seseorang yang menunjukan akan pedulinya terhadap masyarakat sekitar atau orang lain di sekitarnya

r) Tanggung jawab, yaitu sikap seseorang ataupun prilaku dalam menjalankan tugas atau kewajibannya dalam hal tanggung kewajiban diri sendiri masyarakat ataupun agama.

\section{Kreativitas Anak}

Menurut Bayanova (2014) kreativitas adalah manifestasi seseorang sebagai kepribadian yang mengatasi konformisme peraturan yang dibutuhkan, aturan yang diarahkan pada depersonalisasi. Anak adalah sosok individu unik, memiliki sifat dan karakter yang sangat khas dan berbeda dengan individu dewasa. Anak mempunyai perasaan penasaran dan keingintahuan terhadap segala hal yang dilihat, didengar, dan dipelajari secara lebih mendalam yang terlalu tinggi mengenai segala sesuatu yang ada disekitarnya. Anak tidak 
akan berhenti bertanya tentang suatu hal yang ia ingin ketahui sampai ia benar-benar menemukan jawaban yang memuaskan atas pertanyaan yang diajukan. Selain itu, anak juga adalah individu yang sangat aktif, dinamis, memiliki daya imajinasi yang tinggi dan sifat egosentris yang selalu melekat di dalam dirinya. Popescu (2015). Dampak pendidikan terhadap kreativitas penting dan penelitian saat ini berfokus pada bagaimana menciptakan lingkungan yang menguntungkan untuk kinerja kreatif, tanpa mengabaikan korelasi antara motivasi orientasi (intrinsik dan ekstrinsik) dan karakter kepribadian yang kreatif.

Ilmu yang didapat oleh anak akan sangat bermakna karena anak sendirilah yang membangun pengetahuannya. Hakikat anak belajar ialah melalui kegiatan yang menyenangkan dan itu tertuang dalam kegiatan bermain. Yanuarita (2014) memaparkan bahwa didalam keadaan bermain dengan antusias, anak mendapat peluang dengan leluasa untuk mengadakan pengkajian dan penyelidikan untuk merespons rasa ingin tahu, anak dengan leluasa mengungkapkan pemikirannya melalui angan-angan, cerita atau kisah (drama), bermain hal-hal yang bermanfaat, luas dan sebagainya. Pengkajian dan penyelidikan guna mengembangkan pengetahuannya.

Berdasarkan permasalahan tersebut, pengkaji memperhatikan pentingnya untuk mengadakan pengkajian yang berhubungan dengan persiapan pembelajaran, proses pembelajaran, evaluasi pembelajaran yang dilaksanakan dengan memanfaatkan secara baik hasil dari kegiatan pengembangan kreativitas tersebut.

Pijakan lingkungan bermain yang berisikan kegiatan penataan materi dan perlengkapan permainan yang akan hendak dipergunakan didalam kegiatan penyambutan anak. menurut Suyadi (2010) mengatakan bahwa pijakan lingkungan bermain dilaksanakan dengan cara: pendidik lebih aktif dari pada peserta didik, karena pendidik harus mempersiapkan lingkungan bermain, sehingga sebelum peserta didik masuk, telah tersusun rapi dan siap dipergunakan untuk bermain.

Pijakan selama main dilakukan ketika proses bermain di dalam kegiatan berlangsung. Kegiatan-kegiatan dalam pijakan ini menurut Sujiono (2010) memuat hal yang berguna menyampaikan durasi waktu anak didik agar dapat menjalankaan dan mengkaji keahlian bermain, memeragakan contoh berkomunikasi yang baik dan tepat, memperkokoh dan meluaskan pemahaman bahasa anak didik, memperluas peluang pemasyarakatan meniti dukungan (support) interaksi dengan teman seangkatan, memperhatikan dan mengarsip dokumen-dokumen perkembangan dan kemajuan bermain peserta didik.

Dalam memupuk dan mengembangkan kreativitas pada anak-anak, Rogers menyatakan bahwa salah satu kondisi yang turut mendukung adalah kemampuan yang terdapat dalam diri pribadi anak-anak tersebut seperti intelegensi dan kemampuan berpikirnya dalam memahami konsep-konsep melalui bermain. Dan yang dimaksud dengan bermain di sini adalah bermain secara spontan dengan ide-ide, benda-benda, dan dengan anak-anak lainnya. Hal ini berkaitan dengan kelangsungan terhadap keahlian dan pengetahuan yang baru.

Hurlock mengungkapkan bahwa bermain adalah semua program kegiatan yang akan dilaksanakan untuk kebahagiaan yang diakibatkan, dengan tanpa memperhitungkan bagaimana dengan hasil akhir nanti. Anak dapat mencoba hal-hal yang belum diketahuinya serta mengungkapkan ide-idenya melalui bermain bebas. Anak yang masih kecil pastinya hendak dapat merasakan perasaan yang lega bersama-sama dengan apapun yang dihasilkannya. Tetapi, anak-anak sudah lebih besar, akan lebih kritis dan akan lebih berkreasi dalam menciptakan hasil karyanya. Ia akan memperoleh kepuasan pribadi karena dapat menciptakan sendiri suatu hasil karya nyata, disamping itu juga karena ia akan berhasil mendapatkan pengakuan dari lingkungannya terhadap hasil karya tersebut. Dengan demikian, pengalaman-pengalaman kreatif yang diperoleh anak dari 
bermain akan merangsangnya untuk melakukan akivitas yang bermanfaat sebagai sarana mengembangkan kreativitas apabila dia dewasa. Maka sangatlah penting untuk memberikan kesempatan kepada anak mengekspresikan minat-minat serta daya kreasinya melalui sarana bermain.

\section{Kebudayaan Lokal}

Utari, (2016) pengertian kearifan lokal merupakan "kecendikiawanan terhadap kekayaan setempat atau suatu daerah yang berbentuk pemahaman, keyakinan, aturan, aturan tingkah laku, kebudayaan, pengetahuan dan lain sebagainya yang merupakan aset peninggalan dan harus dijaga serta dilindungi bagaikan sebuah tanda pengenal dan panduan pegangaan dalam mendidik dan mengajarkan kita untuk bersikap secara benar dalam kehidupan masyarakat".

Berdasarkan pengertian kearifan lokal yang telah dipaparkan kita bisa menarik kesimpulan bahwa apa yang dimaksudkan dengan kearifan lokal merupakan segala sesuatu yang merupakan potensi dari suatu daerah serta hasil pemikiran manusia maupun hasil karya manusia yang mengandung nilai yang arif dan bijaksana serta dilestarikan secara turun temurun dari nenek moyang terhadap kita sehingga menjadi ciri khas daerah tersebut. Pengintegrasian kearifan lokal dalam pembelajaran sebagai untuk meningkatkan rasa cinta kearifan lokal di lingkungannya serta sebagai upaya menjaga eksistensi kearifan lokal dipertengahan masyarakat arus globalisasi dizaman sekarang semakin cepat dirasakan dalam kehidupan ini.

Pentingnya pengintegrasian kearifan lokal dalam pembelajaran didukung oleh beberapa penelitian diantaranya adalah pengkajian yang dilaksanakan oleh Utari (2016) dengan judul "Pembelajaran Tematik Berbasis Kearifan Lokal di Sekolah Dasar dalam Menghadapi Masyarakat Ekonomi Asean (MEA)" dalam pengkajiannya menyatakan bahwa kearifan lokal menjadikan sangatlah menjadi hal terpenting dengan memperhatikan bahwa proses pembelajaran yang berlangsung dikelas sehari-hari, terkhususnya pada peserta didik sekolah dasar seharusnya dapat diawali dengan lingkungan yang paling terdekat atau yang selalu ditemui oleh peserta didik. Mutu nilai-nilai kearifan lokal hendaklah akan mempermudah peserta didik dalam mengerti setiap rancangan didalam bahan materi mengakibatkan kesediaan pemikiran dan pemahaman yang didapatkan peserta didik tidak semata-mata hanya sampai pada sebatas pemikiran dan pemahaman saja, namun juga harus bisa untuk melaksanakan sesuatu hal dalam diri peserta didik dalam merealisasikan penerapan sesuatu hal tersebut diluar sekolah. Pembelajaran tematik berbasis kearifan lokal akan membuat hubungan di dalam pengertian dan pemahaman peserta didik untuk dapat berperilaku secara benar di dalam menjumpai MEA. Kemajuan yang tidak hanya mengharuskan seorang individu tidak hanya untuk sekedar mencapai keingintahuannya, namun juga harus serba bisa mengusai segala hal pendidikan untuk membantu usaha memajukan Negara. Dalam sebuah kajian, Utaminingsih, Utomo dan Zamroni (2017) menyebutkan menjadi penting untuk kembali membangkitkan karakter keIndonesia-an agar pembelajaran selain menuju pada penguasaan teknologi juga menuju pada pengembangan potensi dan karakter lokal Indonesia semakin kuat. Dalam hal ini, Zamroni (2016) menemukan bahwa salah satu karakter yang tumbuh dan berkembang di sekitar Jawa Tengah utamanya kabupaten Kudus adalah karakter Gus Ji Gang, yakni memiliki akhlak yang baik (Gus), kompetensi dan kemampuan intelektual yang mumpuni (Ji) dan kemampuan secara kreatif mempertahankan hidup melalui kegiatan berwira usaha.

Selain itu, Efendi (2011) memaparkan pentingnya implementasi nilai-nilai budaya lokal dalam pembelajaran IPS dapat dikaji dari filsafat pendidikan yang mendasarinya yaitu Perenialisme. Dalam sudut pandang agama memperhatikan pendidikan sebagai suatu perubahan yang begitu sangat penting untuk diperhatikan di dalam pelestarian dalam hal 
pewarisan nilai budaya para leluhur khususnya kepada anak didik. Nilai-nilai moral budaya yang dimiliki oleh masyarakat sangatlah penting yang berguna untuk membantu perubahan yang signifikan dalam dunia pendidikan, sehingga mengakibatkan sesuatu hal ilmu pengetahuan dapat dimengerti, didapat dan dapat diamalkan oleh anak didik.

Perenialisme memandang bahwa masa lalu adalah sebuah mata rantai kehidupan umat manusia yang tidak mungkin diabaikan. Wagiran (2011) juga melakukan penelitian mengenai pengembangan model pembelajaran pengetahuan dan pemahaman berbasis kearifan lokal. Dalam penelitiannya ditemukan hasil bahwa pendidikan berbasis kearifan sangat perlu diterapkan.

Pernyataan tentang pentingnya pembelajaran berbasis kearifan lokal tersebut berdasarkan dengan apa yang menjadi tujuan pendidikan yang hendak dicapai sebagai salah satu usaha pelestarian warisan budaya para leluhur (nenek moyang). Pernyataan tersebut didukung oleh (Daryanto, 2014:1) bahwa melalui pendidikan, nilai-nilai luhur kebudayaan hendaknya dapat diperkenalkan kepada peserta didik serta dapat dikembangkan sehingga peserta didik mampu menjadi pewaris yang bangga serta mampu mengembangkan budaya bangsa.

Berdasarkan penjabaran tersebut di atas kita mampu menarik sebuah kesimpulan bahwa kearifan lokal bukan hanya tepat diterapkan dalam pembelajaran yang bermanfaat untuk meningkatkan pengetahuan siswa serta sebagai penanaman karakter dan membekali siswa untuk menghadapi segala permasalahan di luar sekolah. Dikarenakan penyelenggaraan pendidikan mempunyai peran dan fungsi yang sangatlah penting di dalam pengenalan serta pewarisan budaya maka pembelajaran pengetahuan dan pemahaman berbasis kearifan lokal sangat tepat diterapkan di sekolah. Khusunya sekolah dasar karena sekolah dasar adalah adalah tahap awal peserta didik memperoleh pengetahuan dan sebagai dasar sebelum melangkah menuju pengetahuan seterusnya dalam tingkatan yang lebih tinggi.

\section{KESIMPULAN}

Dapat disimpulkan dari kegiatan SGK (Sekolah Gencar Karakter) ini menimbulkan beberapa perubahan dalam pola perilaku anak dalam kehidupan keseharian. Adapun karakter yang dibentuk di sini adalah saling menghargai, kemandirian, toleransi, jujur, disiplin, bertanggung jawab, sopan santun, suka bermusyawarah, religius, mencintai kearifan lokal, keberanian, dan sebagainya. Sehingga dapat menyelesaikan permasalahan-masalahan tentan karakter anak pada lingkungan masyarakat. Sehingga anak menjadi anak yang berkarakter baik, dapat diterima dan menerima dimasyarakat, dapat memilah yang baik dan benar serta mencintai kearifan lokal yang ada di sekitar.

\section{DAFTAR PUSTAKA}

Bayanova. L. (2014). Compliance with Cultural rules of children Having Different Level of Creativity. Creativity Research Journal, (Online). Vol 146, 192-195. Tersedia di (http://creativecommons.org/licens es/by-nc-nd/3.0/) diakses pada tanggal 04 Desember 2017.

Dahliani, S, I, \& Setijanti, P. (2015). Local Wisdom in Built Environment in Globalization Era. International Journal of Education and Research, 3 (6): 157-166.

Daryanto. (2014). Pendekatan Pembelajaran Saintifik Kurikulum 2013. Yogyakarta: Penerbit Gava Media.

Dedi, N.. (2010). Akuntansi Sektor Publik. Jakarta: Salemba Empat. 
Efendi, A. (2011). Implementasi Kearifan Lingkungan dalam Budaya Masyarakat Adat Kampung Kuta sebagai Sumber Pembelajaran IPS. Edisi Khusus No. 2, Agustus 2011. ISSN 1412-565X.

Hidayatullah, F. (2010). Pendidikan Karakter: Membangun Peradaban Bangsa. Surakarta: UNS Press \& Yuma Pustaka.

http://kbbi.web.id/sosialisasi diunduh pada tanggal 10 April 2016 pukul: 13.00 .

Kesuma, D. Cepi, T, dan Johar, P. (2012). Pendidikan Karakter: Kajian Teori dan Praktik di Sekolah. Bandung : PT. Remaja Rosdakarya.

Mutiah, D. (2010). Psikologi Bermian Anak Usia Dini. Jakarta: Prenada Media Group. hal. 153.

Popescu. (2015). Familial Barriersin the Development of Creativity in Preschoolers. Creativity Research Journal, (Online). Vol 187, 601-606. Tersedia di http://creativecommons.org/licens es/by-nc-nd/4.0/diakses pada tanggal 04 Desember 2017.

Purwanto. (2011). Evaluasi Hasil Belajar. Yogyakarta: Pustaka Pelajar.

Sujiono, Y. (2010). Konsep Dasar Pendidikan Anak Usia Dini. Jakarta: PT Indeks.

Sukiman. (2012). Peningkatan Kreativitas Anak Melalui Model Pembelajaran Beyond Centers And Circle Time (BCCT). (Dimuat dalam Jurnal Paud Volume 6, Edisi Mei 2012), hal. 23.

Suyadi. (2010). Psikologi Belajar PAUD. Yogyakarta: PT Bintang Pustaka Abadi (BiPA).

Suyadi. (2013). Strategi Pembelajaran Pendidikan Karakter. Bandung: PT. Remaja Rosdakarya.

Trisiana, A. (2015). Action for citizenship education of character education using project citizen model at senior high school in Indonesia. International Journal of Education and Psychology in the Community (IJEPC), 5(1 \& 2), 42-53.

Utari, U. (2016). Pembelajaran Tematik Berbasis Kearifan Lokal di Sekolah Dasar dalam Menghadapi Masyarakat Ekonomi Asean (MEA). Jurnal Teori dan Praksis Pembelajaran IPS. Vol. 1 No. 1 April 2016, Issn 2503 - 1201.

Wagiran. (2009). Pengembangan Model Pendidikan Kearifan Lokal di Wilayah Propinsi DIY dan Mendukung Perwujudan Visi Pembangunan DIY Menuju tahun 2025. Yogyakarta: Setda Provinsi DIY.

Wirawan. (2012). Evaluasi: Teori, Model, Standar, Aplikasi, dan Profesi. Depok: PT. Raja Grafindo Persada.

Yanuarita, F. 2014. Rahasia Otak \& Kecerdasan Anak. Yogyakarta: Teranova Books.

Zamroni, E. (2016). Counseling Model Based on Gusjigang Culture: Conceptual Framework of Counseling Model Based on Local Wisdoms in Kudus. GUIDENA: Jurnal Ilmu Pendidikan, Psikologi, Bimbingan dan Konseling, 6(2), 116-125. 